\title{
Morphology of the Lingual Papillae in the Least Weasel (Mustela nivalis)
}

\author{
Morfología de las Papilas Linguales en la Comadreja Común (Mustela nivalis)
}

\author{
Neveen E. R. El Bakary* \& Shoichi Emura ${ }^{* * *}$
}

EL BAKARY, N. E. R. \& EMURA, S. Morphology of the lingual papillae in the least weasel (Mustela nivalis). Int. J. Morphol., 34(1):305-309, 2016.

SUMMARY: The dorsal surface structure of the lingual papillae in the least weasel was compared with that of other carnivorous mammalian species. Two types of mechanical papillae (filiform and conical) and two types of gustatory papillae (fungiform and vallate) were observed. The filiform papillae had secondary processes. Rarely conical papillae were observed. A few taste buds were seen on the surfaces of the fungiform papillae. The four vallate papillae were located on both sides of the posterior end of the lingual body. In conclusion, morphological characteristics of the lingual papillae and their distribution in the least weasel were similar to those of the Japanese marten and ferret. The conical papillae in the lingual apex of the Japanese marten and ferret were not observed, but the conical papillae were seen in the lingual apex of the least weasel.

KEY WORDS: Lingual papillae; Least weasel; Mustela nivalis; Morphology.

\section{INTRODUCTION}

The definite characters of the dorsal lingual surface in mammals were the shape and distribution of the lingual papillae. The papillae on the lingual surface were closely related to the animal diet and feeding habits (Iwasaki, 2002; Kumar \& Bate, 2004; Erdogan et al., 2015). Much work has been published on the structures of the lingual surfaces in various animals. In the order Carnivora, there have been many SEM studies of the tongues of cat (Boshell et al., 1982; Kobayashi et al., 1988), dog (Iwasaki \& Sakata, 1985; Kobayashi et al., 1987), mongoos (Iwasaki et al., 1987), Japanese weasel (Furubayashi et al., 1989), sea otter (Shimoda et al., 1996), Asian black bear (Inatomi \& Kobayashi, 1999), bush dog (Emura et al., 2000), panther and Asian black bear (Emura et al., 2001), lion (Emura et al., 2003), tiger (Emura et al., 2004), silver fox (Jackowiak \& Godynicki, 2004), raccoon dog and fox (Emura et al., 2006), Japanese marten (Emura et al., 2007), ferret and Siberian weasel (Emura, 2008) and ferret (Takemura et al., 2009). Such studies reveal variations in the structure and distribution of papillae on the dorsal lingual surface among animal species. However, no SEM study of the tongue of the least weasel (Mustela nivalis) has been performed. Therefore, this study examined the dorsal lingual surface of the least weasel and compared the features with those of other mammals.

\section{MATERIAL AND METHOD}

Five tongues of healthy young adult Mustela nivalis were obtained, immediately after their death, from a local hunter. The tongues were rinsed with $0.1 \mathrm{M}$ cacodylate buffer ( $\mathrm{pH}$ 7.4) and specimens bearing lingual papillae were dissected out and fixed in $2 \%$ glutaraldehyde ( $\mathrm{pH} 7.4)$ with cacodylate buffer for $4-6 \mathrm{~h}$ at $4{ }^{\circ} \mathrm{C}$. The samples were then postfixed in $1 \%$ cacodylate-buffered osmium tetroxide at room temperature for 3-5 h. The samples were dehydrated in an ascending series of ethanols and dried, substituting carbon dioxidefor ethanol in a critical point drying apparatus. The specimens were mounted on metal stubs and coated with gold palladium. The specimens were examined in a JEOL Scanning Electron Microscope in EM Unit at Alexandria University.

\section{RESULTS}

The tongue of the least weasel was about $5 \pm 0.25 \mathrm{~cm}$. The tongue was divided into 3 parts; the apex, the body and the root. Four types of lingual papillae were observed in the dorsal lingual surface of the least weasel; filiform, conical, fungiform and vallate. These papillae differed in the structure, number and location.

\footnotetext{
* Zoology Department, Faculty of Science, Damietta University, New Damietta, Egypt.

${ }^{*}$ Nursing Course, Gifu University School of Medicine, Gifu, Japan.
} 


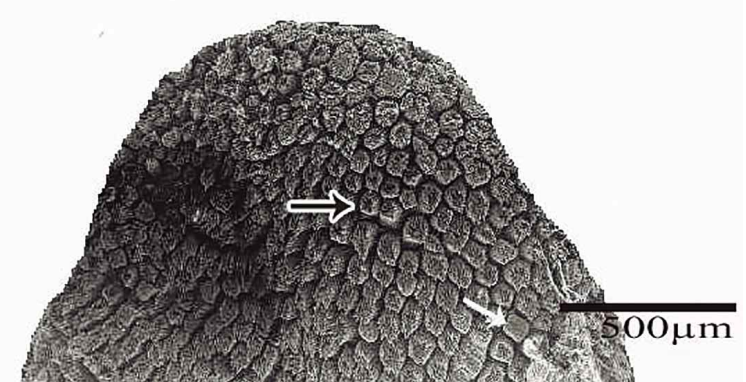

Fig. 1. Scanning electron micrograph of the lingual apex showing the filiform (black arrow) and fungiform papillae (white arrow).

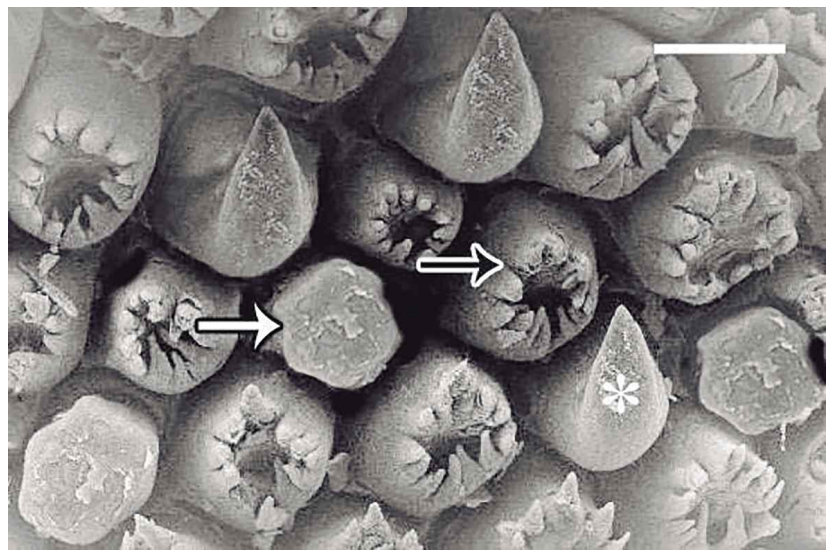

Fig. 2. Scanning electron micrograph of the lingual apex showing the filiform (black arrow), fungiform (white arrow) and conical papillae (asterisk).

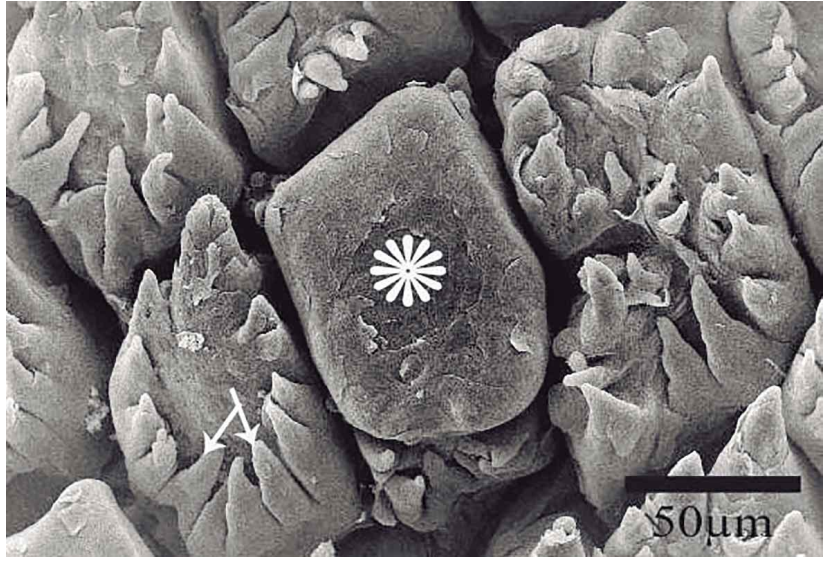

Fig. 3. Scanning electron micrograph of the lingual apex showing the filiform papilla with the secondary processes (white arrow) and fungiform papilla (white star).

Lingual apex. Two types of filiform papillae were found on the dorsal lingual surface. The filiform papillae covered a large area of the whole surface of the tongue. Firstly, overlapping papillae with numerous processes in the direction of the lingual root and had close contact to each other. The tips had ten secondary processes with a leaf-like shape (Figs. 1, 2 and 3). A few numbers of conical papillae were seen in the dorsal surface of the tongue with only one process in the direction of the lingual root (Fig. 2). A few fungiform papillae were found in the apex, body and root.
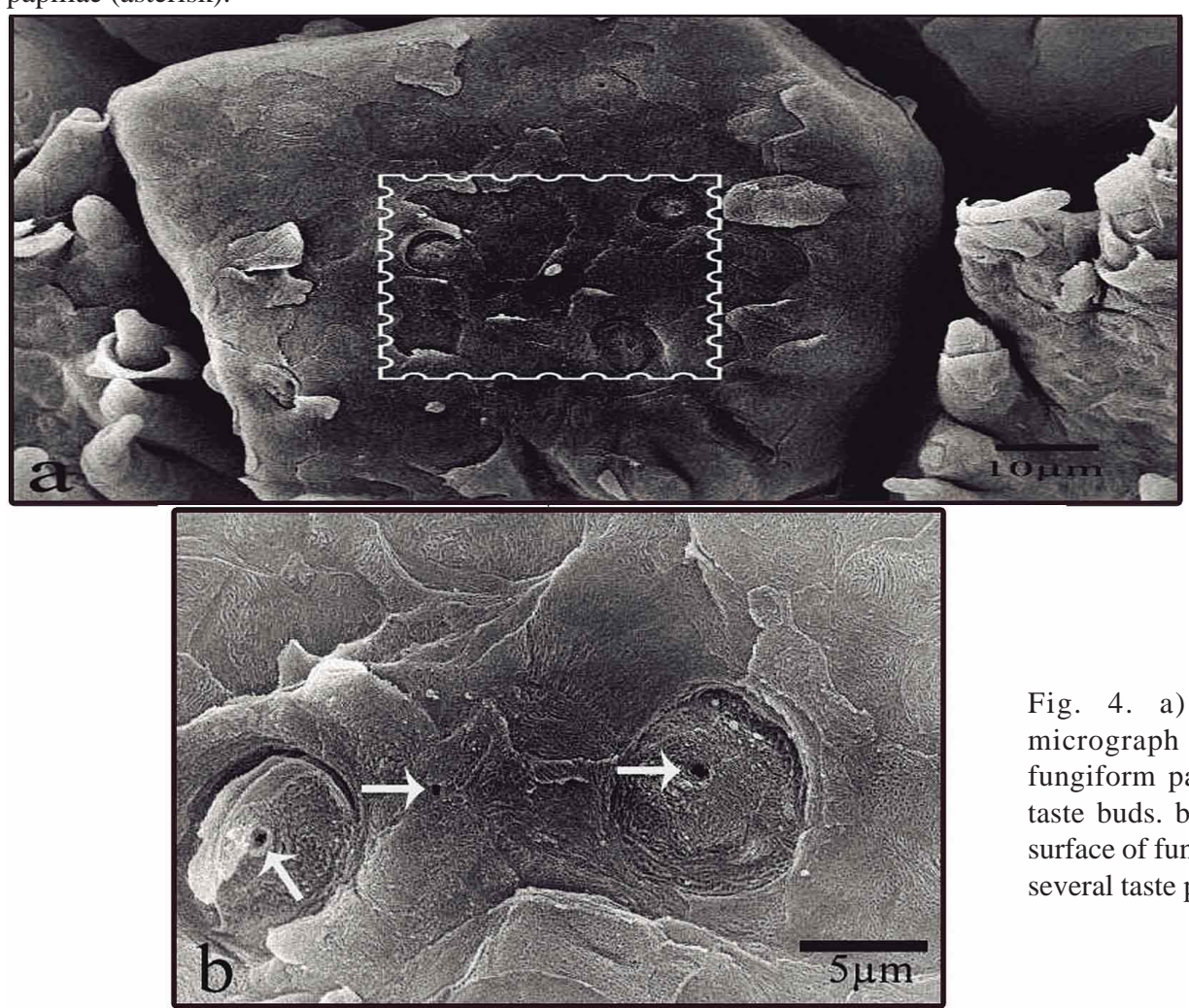

Fig. 4. a) Scanning electron micrograph of the surface of the fungiform papilla showing several taste buds. b) Magnification of the surface of fungiform papilla showing several taste pores (white arrow). 


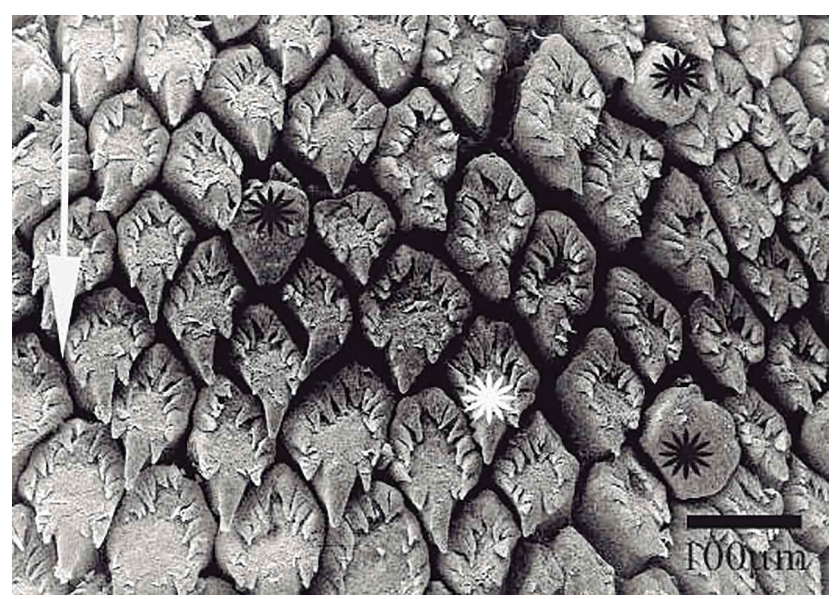

Fig. 5. Scanning electron micrograph of the lingual body showing filiform (white star) and fungiform (black star) papillae. The arrow indicates posterior direction of tongue.

They were sparsely appeared on the filiform papillae. A few taste buds were seen in the dorsal epithelial surface. There were many microgrooves with several microridges on the epithelial surface (Figs. 4a and 4b).

Lingual body. The second types of filiform papillae covered the body of the tongue. They were a leaf-like shape with several pointed edges (Figs. 5 and 6).
Lingual root. Four vallate papillae were observed in the dorsal surface of the root of the tongue; this area was covered by rough mucosa without any types of papillae. These papillae were a rounded bulb-like shape with a central groove. The surfaces of these papillae were smooth and devoid of a taste buds (Figs. 7a and 7b).

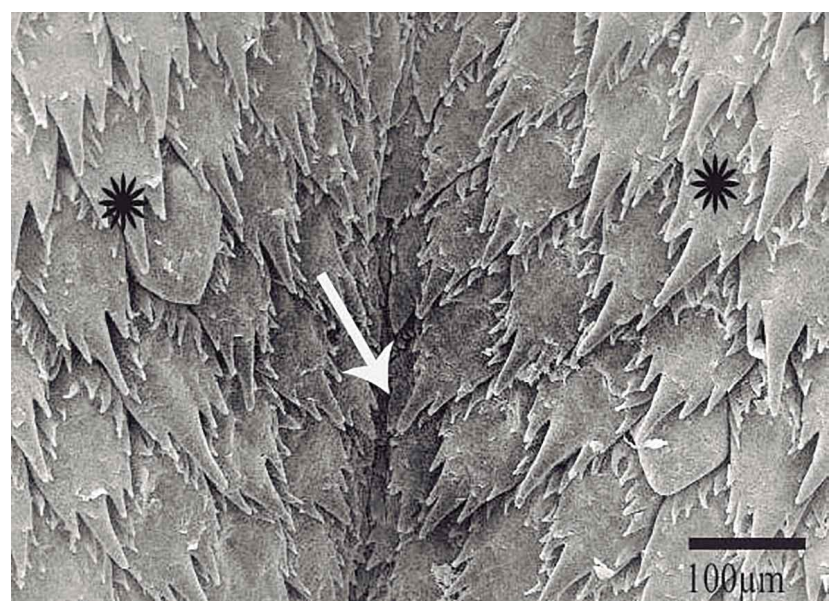

Fig. 6. Scanning electron micrograph of the posterior part of the lingual body showing leaf-like pointed papillae (black star). A white arrow shows a median groove.
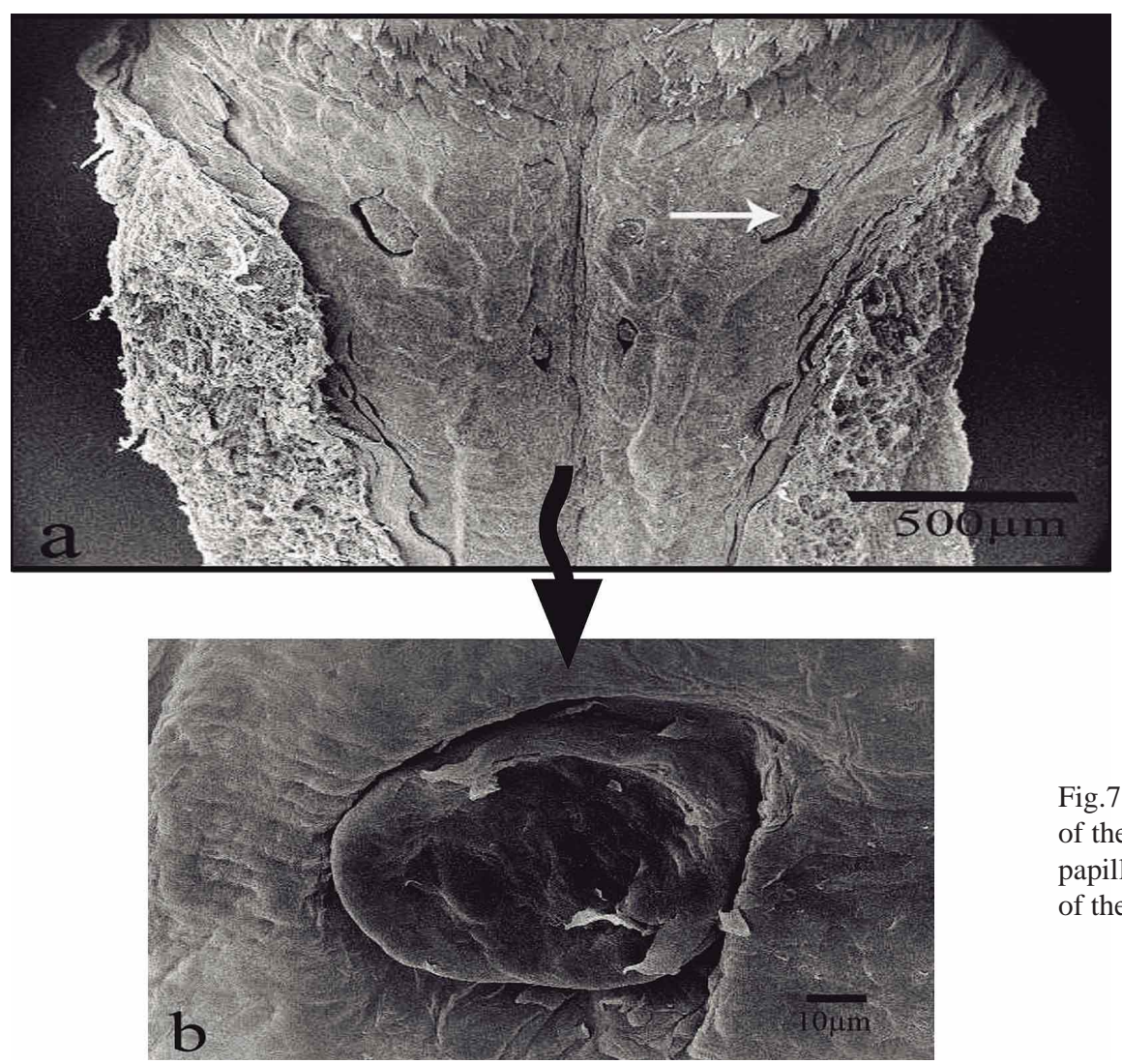

Fig.7. a) Scanning electron micrograph of the lingual root showing four vallate papilla (white arrow). b) Magnification of the vallate papilla. 


\section{DISCUSSION}

Shimoda et al. reported that the filiform papillae on margin of the tongue of the newborn sea otter were divided into two shapes which were horny or club-shaped papillae, and the fungiform papillae also were divided into two shapes which were hemispherical or club-shaped papillae. Emura et al. $(2001,2003)$ described that the large papillae were observed on margins of the lingual apexes of the newborn panther, newborn asian black bear and lion. In the cat (Boshell et al.), newborn panther (Emura et al., 2001), lion (Emura et al., 2003) and tiger (Emura et al., 2004), a marked transition occurred between the tip and midportion of the dorsum of the tongue. The transition was characterized by an increase in size of the projection of the filiform papillae. In the midportion of the tongue, the projections were very prominent. In the silver fox (Jackowiak \& Godynicki), the filiform papillae on the anterior part of the tongue were divided into 1 main and 10 12 accessory processes. In the posterior part of the body of the tongue the number of accessory processes was reduced. In the raccoon dog (Emura et al., 2006), each filiform papilla on the apical surface of the tongue had several pointed processes, and the filiform papillae of the lingual body consisted of a main papilla and some secondary papillae. In the Japanese marten (Emura et al., 2007). A small filiform papilla on the apical surface of the tongue had several pointed processes. A large filiform papilla of the lingual body consisted of a main papilla and some secondary papillae. In the ferret and Siberian weasel (Emura), a filiform papilla on the apical surface of the tongue had several pointed processes. A filiform papilla of the lingual body consisted of a main papilla and one or two secondary papillae.

The conical papillae in the lingual apex of the Japanese marten (Emura et al., 2007) and ferret (Takemura et al.) were not observed. In the present study, a few numbers of conical papillae were seen in the lingual apex with only one process in the direction of the lingual root.

In the present study, there were dome-shaped fungiform papillae scattered among the filiform papillae. Similar SEM studies have been reported on the dorsal lingual surface of the other mammals (Emura; Emura et al., 2000, 2003, 2004, 2006, 2007; Jackowiak \& Godynicki).

Many works have been published on the threedimentional structure of the vallate papillae in the mammalian tongue. The vallate papillae of the cat, dog and flying squirrel were encircled by the filiform papillae in the posterior body (Boshell et al.; Iwasaki \& Sakata; Emura et al., 1999). The vallate papillae of the bush dog were surrounded by a groove and crescent pad, and in the dorsal surfaces of the papillae small conical papillae were observed (Emura et al., 2000). Some vallate papillae of the Asian black bear were composed by a primary papillae which was divided into several secondary papillae by intermediate grooves (Emura et al., 2001). The dorsal surfaces of the vallate papillae in the tiger, raccoon dog and fox were irregular (Emura et al., 2004, 2006). The surfaces of the vallate papillae in the silver fox were smooth (Jackowiak \& Godynicki). In the Japanese marten, the four vallate papillae were located on both sides of the posterior end of the lingual body and each papilla was surrounded by groove and crescent pad. In the ferret and Siberian weasel, the four or six vallate papillae were located on both sides of the posterior end of the lingual body and each papilla was surrounded by groove.

In conclusion, morphological characteristics of the lingual papillae and their distribution in the least weasel were similar to those of the Japanese marten and ferret. However, the conical papillae were seen in the lingual apex in the least weasel.

EL BAKARY, N. E. R. \& EMURA, S. Morfología de las papilas linguales en la comadreja común (Mustela nivalis). Int. J. Morphol., 34(1):305-309, 2016.

RESUMEN: La estructura de la superficie dorsal de las papilas linguales en la comadreja se comparó con la de otras especies de mamíferos carnívoros. Se observaron dos tipos de papilas mecánicas (filiformes y cónicas) y dos tipos de papilas gustativas (fungiformes y circunvaladas). Las papilas filiformes presentaron procesos secundarios. En raras ocasiones se observaron papilas cónicas. Unas pocas papilas gustativas fueron observadas en las superficies de las papilas fungiformes. Las cuatro papilas circunvaladas se encuentran a ambos lados de la parte posterior de la lengua. En conclusión, las características morfológicas de las papilas linguales y su distribución de la comadreja menor fueron similares a los de la marta y hurones japonés. No se observaron papilas cónicas en el ápice de la lengua de la marta y hurón japonés, pero si en el ápice de la lengua de la comadreja común.

PALABRAS CLAVE: Papilas linguales; Comadreja común; Mustela nivalis; Morfología. 


\section{REFERENCES}

Boshell, J. L.; Wilborn, W. H. \& Singh, B. B. Filiform papillae of cat tongue. Acta Anat. (Basel), 114(2):97-105, 1982.

Emura, S. SEM studies on the lingual papillae and their connective tissue cores of the ferret and Siberian weasel. Med. Biol., 152:48-56, 2008.

Emura, S.; Hayakawa, D.; Chen, H. \& Shoumura, S. Morphology of the dorsal lingual papillae in the newborn panther and Asian black bear. Okajimas Folia Anat. Jpn., 78(5):173-7, 2001.

Emura, S.; Hayakawa, D.; Chen, H. \& Shoumura, S. SEM and gross study on the lingual surface of the lion, Panthera leo. Mamm. Sci., 43(1):45-50, 2003.

Emura, S.; Hayakawa, D.; Chen, H. \& Shoumura, S. Morphology of the lingual papillae in the tiger. Okajimas Folia Anat. Jpn., 81(2-3):39-43, 2004.

Emura, S.; Okumura, T. \& Chen, H. Morphology of the lingual papillae in the Japanese marten. Okajimas Folia Anat. Jpn., 84(2):77-81, 2007.

Emura, S.; Okumura, T.; Chen, H. \& Shoumura, S. Morphology of the lingual papillae in the raccoon dog and fox. Okajimas Folia Anat. Jpn., 83(3):73-6, 2006.

Emura, S.; Tamada, A.; Hayakawa, D.; Chen, H.; Jamali, M.; Taguchi, H. \& Shoumura, S. SEM study on the dorsal lingual surface of the flying squirrel, Petaurista leucogenys. Ann. Anat., 18l(5):495-8, 1999.

Emura, S.; Tamada, A.; Hayakawa, D.; Chen, H. \& Shoumura, S. Morphology of the dorsal lingual papillae in the bush dog (Speothos venaticus). Okajimas Folia Anat. Jpn., 77(5):13741,2000

Erdogan, S.; Villar Arias, S. \& Pérez, W. Morphology of the lingual surface of South American fur seal (Arctocephalus australis) and sea lion (Otaria flavescens). Microsc. Res. Tech., 78(2):140-7, 2015.

Furubayashi, R.; Sato, E. \& Ishibashi, T. Histological pattern of the tongue in the Japanese weasels, Mustela itatsi, with special reference to the morphology and distribution of papillae, taste buds and lingual glands. Kaibogaku Zasshi, 64(3):210-4, 1989.

Inatomi, M. \& Kobayashi, K. Comparative morphological studies on the tongue and lingual papillae of the Japanese black bear (Carnivora) and the mountain goat (Artiodactyla). Shigaku, 87:313-28, 1999.

Iwasaki, S. Evolution of the structure and function of the vertebrate tongue. J. Anat., 201(1):1-13, 2002.
Iwasaki, S.; Miyata, K. \& Kobayashi, K. Comparative studies of the dorsal surface of the tongue in three mammalian species by scanning electron microscopy. Acta Anat. (Basel), 128(2):140-6, 1987.

Iwasaki, S. \& Sakata, K. Scanning electron microscopy of the lingual dorsal surface of the beagle dog. Okajimas Folia Anat. Jpn., 62(1):1-13, 1985.

Jackowiak, H. \& Godynicki, S. The scanning electron microscopic study of lingual papillae in the silver fox (Vulpes vulpes fulva, Desmarest, 1820). Ann. Anat., 186(2):179-83, 2004.

Kobayashi, K.; Miyata, K. \& Iino, T. Three-dimensional structures of the connective tissue papillae of the tongue in newborn dogs. Arch. Histol. Jpn., 50(3):347-57, 1987.

Kobayashi, K.; Miyata, K.; Iwasaki, S. \& Takahashi, K. Three dimensional structure of the connective tissue papillae of cat lingual papillae. Jpn. J. Oral Biol., 30(6):719-31, 1988.

Kumar, S. \& Bate, L. A. Scanning electron microscopy of the tongue papillae in the pig (Sus scrofa). Microsc. Res. Tech., 63(5):2538, 2004.

Shimoda, T.; Nakanishi, E.; Yoshino, S. \& Kobayashi, S. Light and scanning electron microscopic study on the lingual papillae in the newborn sea otter Enhydra lutris. Okajimas Folia Anat. Jpn., 73(1):65-74, 1996.

Takemura, A.; Uemura, M.; Toda, I.; Fang, G.; Hikida, M. \& Suwa, F. Morphological study of the lingual papillae in the ferret (Mustela putorius furo). Okajimas Folia Anat. Jpn., 86(1):1724, 2009.

Correspondence to:

Dr. Neveen El Said Reda El Bakary

Damietta University, Faculty of Science

Zoology Department

New Damietta City

EGYPT

Received: 31-10-2015

Accepted: 29-12-2015

Email: elbakaryneveen@yahoo.com 